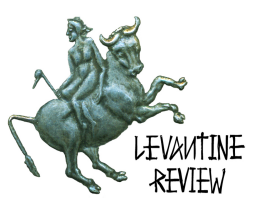

\title{
LEBANON, IDENTITY, DISLOCATION, AND MEMORY
}

\author{
Franck Salameh*
}

Dalia Abdelhady, The Lebanese Diaspora; The Arab Immigrant Experience in Montreal, New York, and Paris (New York and London: New York University Press, 2011), pp. 198, paperback, ISBN 978-0-8147-0734-0

Craig Larkin, Memory and Conflict in Lebanon: Remembering and Forgetting the past (New York and London, Routledge: Taylor\&Francis Group, 2012), pp. 226, hardcover, ISBN 978-0-415-58779-2

In Spring 2012, joining an elite cohort of "immortals,"1 Franco-Lebanese novelist Amin Maalouf was inducted into the prestigious Académie Française. Acceding to the Chair vacated in 2009 by renowned anthropologist Claude Lévy-Strauss, who had himself inherited it from philologist Ernest Renan- "another Lebanese at heart" to use Maalouf's own description-was a nod to a "millennial Franco-Lebanese romance" that many in Lebanon, to this day, still take to heart. ${ }^{2}$ In his elaborate Académie robes, and donning a ceremonial sword, Maalouf further described his new station as recognition of Lebanese distinction, ecumenism, hybridity and cosmopolitanism. Maalouf's coat-of-arms combined a Cedrus Libani (a Cedar of Lebanon symbolizing Phoenician kinship, and maritime expansion); a Marianne (France's national emblem and a symbol of Liberty and Reason); and an image of the "Abduction of Europa" (a Greco-Phoenician allegory of millennial East-West intercourse, in which Maalouf's Lebanon had played a major role since classical antiquity.) All of these motifs were, to Maalouf, illustrative of diversity, humanism, universalism, and multiple identities; parameters of selfhood that Lebanon had been practicing for millennia.

\footnotetext{
1 "The Immortals" is the honorific title bestowed upon members of the Académie Française, and is taken from the official seal coined by the Academy's founder, the Cardinal de Richelieu.

2 Amin Maalouf, "Discours de M. Amin Maalouf," Le Monde, June 14, 2012, p. 2. http://medias.lemonde.fr/mmpub/edt/doc/20120614/1718788_57bc_af-discoursmaalouf1406.pdf
} 


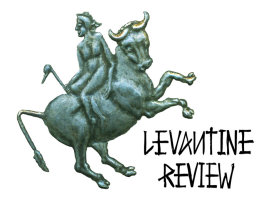

But there is a converse to this pleasing narrative. The foreword of Omar Farrukh's 1961 Arab nationalist creed, Modern Standard Arabism, argued with sinister eloquence the case for Arabist supremacy and the Arab "oneness" of the Middle East. Indeed, Farrukh's book was fittingly dedicated to

those Almoravids standing sentry over the safety of the Arabic language [... ]; to the first line of Mujahideens [...] who have carried aloft the torch of Modern Standard Arabism [...] bringing back tranquility to the Arabs' anxious hearts and lending voice to their strangled throats. To all of those I dedicate these sparse pages, with my highest admiration of their past glories, my utmost appreciation of their current struggles, and my unbounded faith in the glorious future of their looming triumphs. ${ }^{3}$

The fact that Farrukh chose Qoranic terminology in reference to his keepers of Arabism is neither ideologically nor theologically innocent. The Arabic "alMuraabitun"-Anglice "Almoravids" - referred to an eleventh century North African dynasty that played a major role in the Muslim conquest and colonization of Spain. What has been conceded to Islam, that is to say what has become part of dar alIslam, including the Iberian Peninsula, cannot in theory be relinquished or delivered back into the hands of "disbelief" or dar al-Harb - that is to say to an "Abode of War" that is yet to be conceded to Islam. The term "Al-Mujahideen" does not require translation for our times' Anglophones; put simply, it refers to those who wage jihad. Of course, both "al-Murabituun" and "al-Mujahideen" connote those who "struggle," "fight," "exert themselves," and "strive" in the path of Islam. Those terms' Islamic significance and powerful symbolism are seldom lost on Muslim Arabophones steeped in, and sensitive to, this proud tradition.

Rather than undertake a defense and valorization of Arab identity, Farrukh made his case by assaulting those who did not subscribe to his ideology, discrediting their histories and national claims, and expropriating their cultural symbols. Indulging raw emotion and nationalist fancy, Farrukh made the claim that Aramaic, Phoenician, Amharic, and even Pharaonic Egyptian languages, were all dialects of Arabic. " "From the remotest antiquity," he wrote, "the Arabs of the Peninsula no doubt spoke a single language":

However, over time, and for a variety of reasons, their Peninsula became too narrow to contain their natural growth, and they were driven to migrate North and West, to Iraq, Syria, Egypt, and North Africa. These migrations truncated

${ }^{3}$ Omar Farrukh, Al-Qawmiyya al-Fusha [Modern Standard Arabism], (Beirut: Dar al-`Ilm lil-Malayeen, 1961), 5-6.

${ }^{4}$ Farrukh, 8-9.

ISSN: 2164-6678 


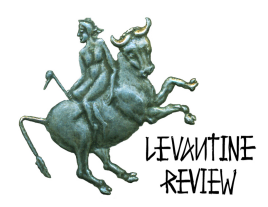

those speakers of a single Arabic language from their kinfolk and from their pristine speech form - which remained, nevertheless, safeguarded in the confines of the Arabian Peninsula. This contributed to the emergence of various dialects of Arabic, which in our days are referred to as Aramaic, Phoenician, Amharic, and Pharaonic Egyptian. And as linguistic harmony dissipated among those kindred Arabs, now speakers of disparate Arabic dialects, conflict ensued and wars erupted among them. Ultimately they each erected their own separate language and their corollary Empires propagating those languages. ${ }^{5}$

The preceding is, of course, shoddy history and flawed distorted linguistics. The claim of Arab tribes spilling out of the Arabian Peninsula and spawning the civilizations and languages of Aram, Canaan, Phoenicia and the rest, prior to Islam, is pure fantasy, based on no known historical or archaeological record. But it's a celebrated Arab nationalist doctrine. Still, it is Islam and the language of its scriptures, claimed Farrukh, that is credited with redeeming the Arabs and their history, and driving them back to the fold of a restituted pristine Arabic language; man's soundest, purest, inimitable first language, the protection of which is incumbent upon all Muslims. ${ }^{6}$

More recently, in a communiqué issued at the close of a 2012 "International Council of the Arabic Language" conference, the organizers called for the "enactment of laws at the national, pan-Arab, and pan-Islamic levels to punish those who treat the Arabic language carelessly, or exclude it from governmental, institutional, commercial, educational, cultural, media, and personal life." ${ }^{7}$ Honorable an endeavor as the protection of the Arabic language might be-indeed, the protection of any language for that matter-there is something profoundly disturbing in the nature of policies promising to mete out punishment based on people's language choices.

Yet for a century or more of Western (and American) academic interest in the modern Middle East and its peoples, scholars, public intellectuals, and analysts have been deeply beholden to an Arabist canon, to Arab predilections, and to strict Arab nationalist taxonomy vis-à-vis an otherwise varied, diverse, multi-cultural and polyglot Middle East.

\footnotetext{
${ }^{5}$ Farrukh, pp. 79-80.

${ }^{6}$ Farrukh, 84.

${ }^{7}$ The Beirut Document, Final Statement of the International Council of the Arabic Language, Beirut, March 2012, http://www.alarabiah.org/index.php?op $=3 \& p o o=302 \&$ pooo $=2$
} 


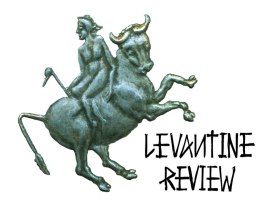

It is in the spirit of unpacking the prevalent image of a monolithic Middle East that Dr. Dalia Abdelhady's tantalizing journey begins. Her enticing title is an invitation to a new discovery of another Middle East. Indeed, The Lebanese Diaspora; The Arab Immigrant Experience in Montreal, New York, and Paris is an important, topical, wellresearched, well-written, and all around fascinating addition to the study of modern Lebanon and the "Lebanese Universe" - le monde libanais, as Saïd Akl termed the Lebanese diaspora.

Yet at various points in her narrative, Dr. Abdelhady, a Senior Research Fellow at the Center for Middle Eastern Studies, Lund University, still manages to fall into the same traps that she took great pains cautioning against at the outset of her study. Even in her Acknowledgments, the author makes the point that to study the Lebanese as a monolith is to denude them of their congenital diversity and slot them in "commonalities of language and culture that are often contested. [...] I was drawn to studying the Lebanese," writes Abdelhady, "specifically as a result of the diversity of the community and the contentions inherent in defining a Lebanese identity" ( $p$. ix.) Indeed, the bulk of the data marshaled by Dr. Abdelhady attested to the Lebanese congenital hybridity, cosmopolitanism, and multiple identities that her book title promised to parse (pp. 85, 96, 188-9, 191-2.)

Yet the author proceeds to do exactly what she set out to avoid. Beginning with the book's very title and subtitle, polar opposites feuding for hearing and clashing for meaning, Abdelhady ends up misleading more than illuminating. One wonders why she promises to investigate a distinct immigrant community ("The Lebanese Diaspora" as her title indicates,) only to end up lumping it into a generic and widely varied "Arab immigrant experience," an ultimately disparate and distinct one from the Lebanese model.

Although she expertly crafts her analysis of the complex and varied ways in which Lebanese diasporic communities view their own identities and integrate into their host societies, Abdelhady still manages to conflate Lebanese and Arab throughout her study. To wit, she gives voice to the children of the "Lebanese Diaspora" defining them, in their own words, as hybrid cosmopolitan polyglots, "product[s] of two or more cultures" (pp. 61-62), "belong[ing] to multiple societies" (p. 192), "a mixture between East and West" (p. 96) and "formed at the intersection of multiple cultures" (p. 84). Yet she deems it appropriate to turn around and claim the "Lebanese Diaspora" to an exclusivist Arab lot, foregoing not only the fluidity and diversity of identity in Lebanon proper and among her own Lebanese respondents, but also throughout the Middle East as a whole.

Clearly, there are tensions and nuances between "being Lebanese" and "being Arab," and negotiating this minefield certainly requires tact and impartiality, especially in 


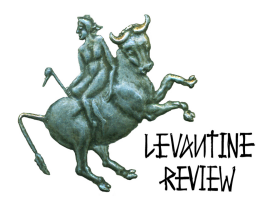

the context of value-free scholarship; that, however, does not seem to warrant Dr. Abdelhady's concern. Her lack of attention to, or perhaps even her contempt for, Lebanese specificity (as in her consistent and continuous reference to Lebanese and Arabs interchangeably, defying scholarly discourse on identity in Lebanon,) seems to be a natural order of things.

The challenges of an ambitious - nay, an audacious-book title such as Abdelhady's is that it presumes the existence of a single coherent Arab collective, and therefore a source of a single "Arab immigrant experience." Yet even the celebrated T.E. Lawrence (Lawrence of Arabia,) one of the twentieth century's most committed advocates of Arabism, scoffed at the idea of a single unitary "Arab nation" and a putative cohesive "Arab people." Lawrence described this assumed uniformity of some Arab Middle East as an illusion, akin to "English-speaking unity [...]; a madman's notion for this [twentieth] century or [the] next."8 Even Arabic linguistic dominance, he noted, did "not mean that Syria-anymore than Egypt-[was] an Arabian country," further adding that on the Mediterranean "sea coast [dwelt] little, if any, Arabic feeling or tradition."9 Yet, Abdelhady's "Arab Immigrant Experience" when considering a uniquely Lebanese model doesn't seem to raise eyebrows. Using Lebanese and Arab tautologically, and expropriating the "experience" of one to the benefit of the other seem to fit snugly into a prevalent-albeit faulty-Arabist conception of the Middle East.

Indeed, the early Lebanese diasporans whom Abdelhady used as foundation to her work would be amazed to learn of their becoming the early immigrant pioneers of some coherent Arab collective. This is to say nothing of their posthumous anointment as Arabs tout court. Incidentally, Franco-Lebanese novelist Amine Maalouf was the only presumptive "Arab immigrant" of note meriting mention in Abdelhady's text and index. This is so perhaps due to Maalouf's passing mention of some inchoate Arabness in some of his writings. In truth, however, Maalouf is an eloquent and vocal opponent of reductive exclusivist identities-Arab and otherwise. "I come from no country, from no city, from no tribe," bragged one of his archetypal narrators, an anthropomorphic representative of the cosmopolitan polyglot Lebanon that Maalouf so valorized.10 "I am the son of the road, a wayfarer," he wrote:

My homeland is the caravan; my life the most spectacular of pathways, the most riveting of travels. [...] My eyes have seen cities die and empires collapse.

\footnotetext{
${ }^{8}$ Ephraim Karsh, Islamic Imperialism: A History (New Haven, Conn. And London: Yale University Press, 2006), 28-9.

${ }^{9}$ Ibid. 128.

${ }^{10}$ Amin Maalouf, Léon l'Africain (Paris: J.C. Lattès, 1986), 9.
} 


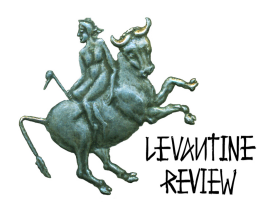

From my mouth you will hear Arabic, Turkish, Castilian, Berber, Hebrew, Latin, and Italian vulgari, because all tongues and all prayers belong to me. But I belong to none. ${ }^{11}$

This is the Lebanese diasporic experience that one might have expected from Dr. Abdelhady's enticing title. Yet the book itself disappoints almost equally as much as it delivers. Still, The Lebanese Diaspora; The Arab Immigrant Experience in Montreal, New York, and Paris is a much needed addition to the literature and sociology of Lebanese immigration to the West; a book of great importance and topicality, and a valuable, competent, and painstaking "breviary" of the demographics, attitudes, selfperceptions, and migratory trends among Lebanese expat communities during the twentieth century.

Alas this is also a book not without failings. To wit, no exploration of the Lebanese diaspora can be deemed complete without prodding at the sources-that is to say without at least giving passing mention to the early Lebanese immigrant communities of the mid-nineteenth century. Furthermore, in an early segment of the book, which the author seems to have reserved to dismissing those Lebanese immigrants who reject a putative "Arab" identity that she insists on ascribing to them (pp. 42-3,) she derisively refers to their "sensual [sic.] reporting on religious persecution and victimization of Christian minorities" in the Middle East. I suspect the adjective Abdelhady might have meant to use here was "sensationalist," not "sensual"- the insinuation being perhaps that the persecution of Near Eastern Christians was a figment of the imagination of some "right wing" Maronite zealots, not a real dilemma in a contemporary Middle East beholden to Arabist oneness and uniformity. Never mind that the ongoing destruction of Near Eastern Christiansthat some cheeky Maronite drama-queen dared bring to light a few years ago-is a phenomenon fourteen centuries in the making; a horrid legacy the recognition of which remains imperative to a sound understanding of the Middle East.

Incidentally, reducing Lebanese Maronite political formations to the simplistic stereotypical category of "right wing" parties-juxtaposed to presumably progressive or "left wing" Muslim and Arabist parties-again, misleads and profoundly misunderstands the intricacies of Lebanon's dynamic political culture and vibrant multiple identities. "The seating arrangements of the first French National Assembly after the Revolution do not express a law of nature," famously wrote Bernard Lewis in 1977, at the height of the Lebanese civil war and in the throes of media banalities and oversimplifications about Lebanon; what's more, added Lewis,

${ }^{11}$ Ibid. 


\section{Salameh / The Levantine Review Volume 1 Number 2 (Fall 2012)}

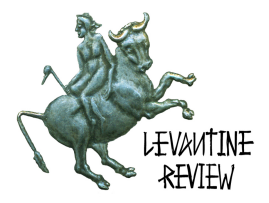

the practice of classifying political ideas, interests and groups as right or left obscures more than it illuminates even in the Western world where it originated. As applied to other societies, shaped by different experiences, guided by different traditions, moved by different aspirations, such imported labels can only disguise and mislead. ${ }^{12}$

Dr. Abdelhady might not be ill-served taking heed of the exquisite complexity of Lebanon's political and cultural traditions as conveyed by Lewis. To be fair, she does occasionally allude to this complexity, for instance when she brings to the fore a group of Lebanese respondents who "emphasized their Phoenician heritage" as a foundation of their ethnic identity (p. 46.) Yet Abdelhady seems to scorn this Phoenicianist notion, and persists in maintaining her respondents' ascribed (almost coerced) Arabness, describing them throughout the work as an "Arab immigrant group," largely to their discontent, and thus giving her work a didactic and flagrantly prescriptive rather than a descriptive framework.

In this same vein, the author discredits another of her respondents who, in her words, "claimed (wrongly) that most Lebanese people are Francophone and Catholic, and thus share the same cultural milieu." But perhaps there is some truth to such a claim? Dr. Abdelhady herself admits earlier in her text that demographic figures are dicey in Lebanon; that the last census dated back to 1932; and that the largest Lebanese-indeed the largest Middle Eastern-immigrant groups remained predominantly Christians - not to say Maronites-from Mount-Lebanon (pp. 5, 412, and 199.) Perhaps Selim 'Abou, a leading Lebanese cultural anthropologist and an authority on Lebanese diaspora studies could have offered some insights. The Maronite diaspora demographics that his work provides, number in the millions; by far exceeding the entire population figures of Lebanon proper. Curiously enough, 'Abou's crucial work and statistics are conspicuously absent from a study where they should have figured prominently.

Likewise, Abdelhady's attribution of some Lebanese immigrants' negation of their imputed Arabness, to post-colonial theory and to Lebanon's so-called colonial past grossly misunderstands and oversimplifies Lebanese history. 'Abou argued that notwithstanding Lebanon's millennial history and the various and often contradictory interpretations of that history, the Lebanese endogenous and congenital diversity, cultural hybridity, and polyglossia remain evident, and precede the age of colonialism. He maintained that:

From the very early dawn of history up to the conquests of Alexander the Great, and from times of Alexander until the dawning of the first Arab Empire, and

${ }^{12}$ Bernard Lewis, From Babel to Dragomans (NY: Oxford University Press,) 289. 


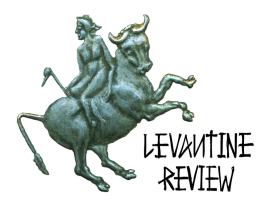

finally, from the coming of the Arabs up until modern times, the territory we now call Lebanon-and this is based on the current state of archaeological and historical discoveries - has always practiced some form of bilingualism and polyglossia; one of the finest incarnations of intercultural dialogue and coexistence. $^{13}$

Alas, the fashionable fad of attributing the rejection of Arabism by some LebaneseMaronites in the main -fails to take into account that "French colonialism" in its Lebanese context differed markedly from France's colonial experience elsewhere. For one, the "founding fathers" of modern Lebanon lobbied vigorously for turning their post-Ottoman mountain Sanjak into a French protectorate after World War I. ${ }^{14}$ Indeed, argued Selim Abou, Lebanon's privileging of a distinct non-Arab identity is a way of heeding history; hardly a colonialist throwback and the outcome of early twentieth-century French imperialism..$^{15}$ And contrary to the classical norms in the expansion and transmission of imperial languages - the spread of Arabic includedwhich often entailed conquests, massacres, and cultural suppression campaigns, the French language can be said to have been adopted willingly by the Lebanese, through "seduction" not "subjection."16

Even post-colonialism's most notable theoretician, Edward Said himself, whom Abdelhady brandishes liberally, seems to have tempered his resentments later in life. In a discussion to which Syrian poet Adonis had been privy in New York, Said was reported to have argued against the concepts of homeland, nationalism, and even Arabism, dismissing them as "caricature, hyperbole [...], and romantic yearning that no longer appealed to [Said.]"17 Indeed, "peregrinations and wandering off from one place to the next" are what Said loved most about his own life. ${ }^{18}$ What's more, Said called New York "home" precisely because of its "ever-changing, multi-colored chameleon-like attributes, allowing one to belong to New York without issuing from her and without being held captive to her." 19 In that sense, places where the erstwhile Arabist Said grew up, Ramallah for instance, left him utterly unmoved, and can hardly be considered a "homeland" at all. ${ }^{20}$ Not only is it possible for man to

\footnotetext{
${ }^{13}$ Selim 'Abou, Le bilinguisme Arabe-Français au Liban (Paris: Presses Universitaires de France, 1962,) 157-8.

${ }^{14}$ See, for instance, Meir Zamir's The Formation of Modern Lebanon (Ithaca: Cornell University Press, 1988.)

15 'Abou, 169-95.

16 'Abou, 191-5.

${ }^{17}$ Adonis, Ra's al-Lugha, Jism al-Sahra', (Beirut, Lebanon: Al-Saqi Books, 2008,) 15.

18 Ibid.

19 Ibid.

${ }^{20}$ Ibid.
} 


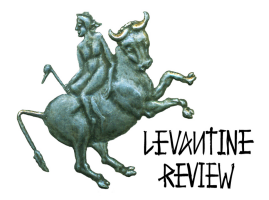

wield "multiple identities" claimed Edward Said, multiplicity, hybridity, and composite identities should be man's very mission and ambition. ${ }^{21}$ This is nothing if not peculiarly reminiscent of the Lebanese immigrants that Abdelhady's work took great pains at either deriding or forcibly Arabizing. Indeed, this is a clear echo of Maalouf's very conception of identity, as a construct never pinned down by narrowness of name, language, ethnicity, or religion (pp. 61-2, 91, and 94-6.)

Furthermore, it is remarkable that Dr. Abdelhady's definition of Arabness yielded humanism, malleability, and inclusiveness that seemed even compatible with Amine Maalouf's own conceptions of hybridity and multiplicity of identities. This is all the more interesting when both textually and empirically the history of Arab nationalism has been anything but valorizing of diversity, ecumenism, and acceptance of the "other" as such. Sati' al-Husri (1880-1967), a Syrian writer considered by many the guiding spirit of Arab nationalism, unabashedly advocated for a forced Arabization of those who partook of non-Arab identity parameters. ${ }^{22}$ Indeed, Husri bragged about the fascistic impulses of the Arab identity that he promoted; "we can say that the system to which we should direct our hopes and aspirations [as Arab nationalists] is a Fascist system," he famously wrote. ${ }^{23}$ Echoing this sinister attitude, Husri's disciple and co-founder of the Baath Party, Michel Aflaq (1918-1989), called for the extermination of those who refused to conform to his prescribed Arabness. Arab nationalists must be ruthless against those members of the Arab nation who have gone astray from Arabism, wrote Aflaq:

They must be imbued with a hatred unto death, toward any individuals who embody an idea contrary to Arab nationalism. [...] An idea that is opposed to [Arab nationalism] does not emerge out of nothing! It is the incarnation of individuals who must be exterminated, so that their idea might in turn be also exterminated. ${ }^{24}$

Adonis, himself a former Arab nationalist, indicted this kind of venom emanating from Arabism, and argued that a culture that continues to privilege such rigid identity parameters, to the detriment of diversity, is a culture doomed to extinction. "A nation consumed by a need for 'oneness'," he wrote,

\footnotetext{
${ }^{21}$ Ibid.

${ }^{22}$ Abu Khaldun Sati' al-Husri, Abhath Mukhtara fi-l-Qawmiyya al-'Arabiyya (Beirut: Markaz Dirasat al-Wihda al-'Arabiya, 1985,) 80.

${ }^{23}$ William Cleveland, The Making of an Arab Natioanlist: Ottomanism and Arabism in the Life and Thought of Sati' al-Husri (Princeton, NJ: Princeton University Press, 1972,) 127.

${ }^{24}$ Michel Aflaq, Fi Sabil al-Baath (Beirut: Dar at-Tali'a, 1959,) 40-41.
} 


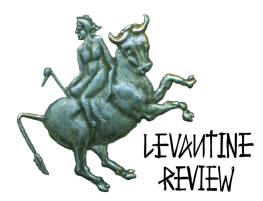

"oneness" in thought, opinion, language, and belief, is a culture of Tyranny, not singularity; it is a collectivity stunting personal and intellectual enlightenment. [...] History beckons to the Arabs to put an end to their culture of deceit; for, [the] states of the Levant are much greater, much richer, and much grander than to be reduced to slavery for the benefit of Arabism. ${ }^{25}$

Yet this is the rigidity and suppression of cosmopolitan humanism and multiple identities that Dr. Abdelhady seems to find appealing in Arabism.

Finally, in examining the etymology of the term "diaspora," the author relates it to the "Greek verb speiro (to sow) and the proposition [sic.] dia (over)" (p. 10.) That, of course, is only half correct, as dia is a preposition, not a proposition, and it really means "across" not "over." Yet Abdelhady's etymology seems spurious-not to say malignant-in another way. It is remarkable that she forgoes mentioning that the term diaspora's earliest Greek use has come down to us through Deuteronomy 28:25, as a Hellenized form of the Hebrew word Galut, in reference to the Jewish sixth century BC dispersion and the destruction of the First Temple in Jerusalem. What's more, the Jewish origins of the term are further obfuscated when we are also told that diaspora "acquired a more sinister and brutal meaning as it signified a collective trauma as in the cases of Africans, Armenians, Jews, and Palestinians"again, withholding the Jewish origins of the expression, and folding the Jewish experience into a twentieth century phenomenon, situating it in more recent traumas; that is to say more than 2500 years following the first Jewish diaspora.

Still, this volume's major flaw remains its profound misunderstanding of the complexity of Lebanon's politics of identity, its disregard of Lebanese history, its frivolous use of the putative term "Arab" in reference to Lebanese groups that would ordinarily take great umbrage at being defined as Arabs, and its perfunctory framing of the Lebanese experience as one of an "Arab immigrant" subgroup, even as, and to the author's own admission at times, the circumstances, framework and agents of Lebanese immigration, as well as the Lebanese historical, national, linguistic, and cultural trajectories, remain markedly distinct and different from those of Arabs proper.

Perhaps Dr. Abdelhady could have taken a cue from a number of her own Lebanese respondents, one of whom for instance maintained that restricting "his cultural repertoire to only one culture [amounted to] social and cultural death" (p. 65.) In the end, probing the Lebanese diasporic experience on its own merits and in its own historical and sociological contexts, or perhaps situating it within a larger, less

${ }^{25}$ Adonis, "Open Letter to President Bashar al-Assad; Man, His Basic Rights and Freedoms, or the Abyss," As-Safir, xBeirut, June 14, 2011. 


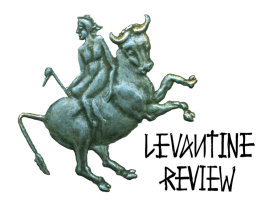

doctrinaire, and ultimately more accurate (and spacious) Middle Eastern cultural space would have given more clarity, more quality, and more scholarly rigor to an otherwise supremely relevant addition to the literature on diaspora studies, the modern Middle East, and modern Lebanese history and identity.

Within a parallel context of dislocation-mental and historiographic this time, rather than purely physical dislocation-Craig Larkin, a Lecturer in Comparative Politics of the Middle East in the Department of Middle East and Mediterranean Studies at King's College London, proposes another, more nuanced illustration of the fluidity, complexity, and diversity of identity and places of memory in modern Lebanon. A book of remarkable originality and substance, Memory and Conflict in Lebanon; Remembering and Forgetting the Past parses the modern history of Lebanon through the prism of post-civil-war remembrances and forgetfulness. As such, Larkin's is an expertly investigated, carefully assayed, and skillfully crafted analysis of Lebanon's 1975-1990 civil war legacy. But Larkin delivers much more than the book title promises. Memory and Conflict in Lebanon is an in-depth, learned, and discerning exploration of Lebanese identities beyond the confines of the civil-war and the post-war era, and certainly past the simplistic binaries that have often saddled prevailing scholarship on Lebanese memory and identity.

Given the nuances of, often the conflicts over, Lebanese history identity and historiography, Larkin offers a subtle and inclusive approach to negotiating the crosscurrents that define and beset Lebanese national identity - and the conflicts over defining this identity. Larkin's premise gives voice to narratives that both "support and critique Lebanese pluralism," presenting Lebanese identity as a dynamic, shifting continuum. In a country with eighteen recognized ethno-religious communities, each with its own conceptions of itself, its memories, its identities, its parameters of loyalties, and its variegated visions of the Lebanese state itself, memory, history, and identity are never unitary, nor even binary in Larkin's telling, but always multi-layered, manifold, and shifting. This is perhaps best encapsulated in the words of one of Larkin's respondents, a university student who defined himself and his identity as follows:

Identity is not stable, you know, identity can change with your mind, how you evolve in your thinking. For example I define myself as Lebanese when I'm outside Lebanon. When I'm inside Lebanon and there is a debate [...], I identify myself as from the North. When I'm in the North, I'm from Zgharta, when I'm in Zgharta, I'm with the Franjeyeh family, when I'm Franjeyeh family, I'm Boustany. When it's Muslim and Christian, I'm Christian (p. 57)

This perspective, in all its simplicity and profundity, could have been taken straight from Amin Maalouf's In the Name of Identity; a most accurate definition of Lebanon's 


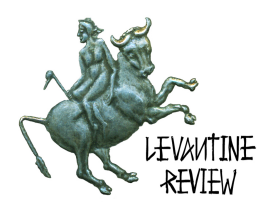

"identities" as multi-layered patchworks of complex unique structures. "Identity isn't given once and for all," writes Maalouf, "it is built up and changes throughout a person's lifetime." Larkin seems to have grasped this reality and this peculiarity of Lebanon's, and he illustrates it with the skill and discernment of an intimate insider. ${ }^{26}$

What makes Larkin's work admirable, beyond its tightly argued analysis, is its sensitivity, and the dignity it renders its subject matter. Avoiding the prevalent didactic approaches to Lebanese history and identity - and even the prevailing established semantics framing inquiry into identities in Lebanon-Larkin provides a dispassionate, sober, nuanced, and all around decent and elegant offering. Take the term "sect" for instance, the foundation of Lebanon's "sectarian" affiliations and its oft-maligned "confessional" system of governance. Larkin goes to great lengths explaining not only the etymology of the term itself-which issues from the Arabic "Ta'ifa" for "confession" or "religious community" — but he also delves into the term's semantic and political connotations, which also point to "social identities," "political orientations," and even "ethnic" or "ethno-religious" categories seldom treated without scholarly contempt elsewhere. This is a far cry from traditional scholarship on Lebanon, which tends to define identities in oversimplified religious terminologies, often attributing the country's divisions to primordial "sectarian" foundations, as juxtaposed to, say, the progressive modern mind's other-ostensibly "secular" - standards of loyalty and agents of conflict.

To the converse of Abdelhady, Larkin shows that Lebanon is more than merely another "Arab" or "Middle Eastern" state. Unlike neighboring Arab-defined polities, which were largely Western concoctions, Lebanon's modern (legal) incarnation is deeply rooted in the history of Ottoman Mount-Lebanon, and even further in the pre-Ottoman identities of the Mountain's populations. While the boundaries of most modern Middle Eastern states were arbitrarily delineated-as is the case with, say, Syria, Iraq, Palestine and the rest-Lebanon's territories have traditionally consisted of Mount-Lebanon proper, and a littoral region extending roughly from Tripoli in the north, to Sidon in the south. This area has had a long tradition of established autonomy, a well-defined identity, and a distinct, often self-ruling populace made up of Christians primarily, most of them Maronites, but with a sizeable Sh'ite, Druze, and other smaller heterodox groups. With its rugged terrain and recalcitrant independent-minded population, Lebanon has long been a refuge for hunted down minorities, a meeting-place for iconoclastic ideas, and a space for freedom and political autonomy where none existed elsewhere in the neighborhood.

${ }^{26}$ Amin Maalouf, In the Name of Identity (New York, NY: Penguin Books, 2003), 23 


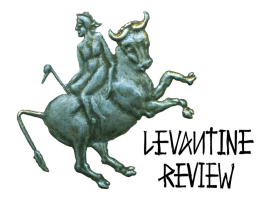

Fouad Ajami wrote that Lebanon has "always been at its heart a Christian homeland" where dissident ideas, libertine mentalities, and varied cultures have traditionally collided, cavorted, fused, and bloomed. ${ }^{27}$ Michel Chiha (1891-1954), one of the architects of modern Lebanon argued that not unlike the Alps to the Swiss people, Lebanon's impregnable "sacred mountains" and its Mediterranean shores possessed remarkable mystical values that molded the distinct identity and independent spirit of the Lebanese. He wrote that

the interpenetration between Mountain and Sea has molded the Lebanese republic. ${ }^{28}[. .$.$] If the Lebanese seek to eke out a living wherever possible, it is$ primarily for the sake of protecting certain beliefs. The Lebanese Mountain is a spiritual sanctuary. All of the religious minorities who live there [...] have found in these high mountains a refuge from oppression, and a haven for freedom. [...] The mystique of Lebanon is in the fact that its Mountain was gradually populated by restless people, by hunted down people. These people had abandoned their possessions behind them, in order to safeguard their lives and their souls. ${ }^{29}$ We are a breed of mountaineer-navigators, markedly different from those people who surround us. ${ }^{30}$

The preceding essentially relates symbols and self-images of Lebanon's nationalist and patriotic canon; a geographic conjugation of Mount-Lebanon and the Mediterranean as a communal hearth where the spirit of a single nation-in spite of its diversity and often fractiousness - is molded, and where sentiments of kinshipwhere none might have existed prior-are kindled and nurtured.

Sectarianism, and its ancillary confessional system in Lebanon, deemed by some the scourge of Lebanese politics, is the result of deeply rooted primordial loyalties-in Lebanon, and for that matter elsewhere the Middle East. Rather than summarily besmirch sectarianism as the root of all evil in Lebanon, Larkin valorizes the lifelong work of Lebanese and foreign sociologists who often concluded that sectarianism and the confessional system in Lebanon were also foundation and agent of the country's cultural diversity and political vitality (p. 42.) Indeed, while confessionalism might have hindered the formation of a unitary cohesive Lebanese identity, it has also been a process "through which a kind of religious identity is politicized, even secularized," ultimately becoming a source of harmony and order to the same extent that it might have spelled tension and disorder (pp. 42-3.) And

${ }^{27}$ Fouad Ajami, "The Autumn of the Autocrats," Foreign Affairs, May-June, 2005.

${ }^{28}$ Michel Chiha, Visage et présence du Liban (Beirut, Lebanon: Editions du TridentFondation Michel Chiha, Second Edition, 1984), 144.

${ }^{29}$ Ibid., 166.

30 Ibid., 147. 


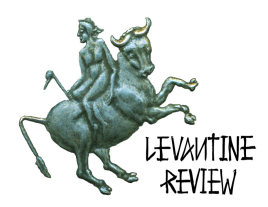

where no traditions of power-sharing, pluralism, and democratic processes and values may have existed in other ethnically diverse states in the Middle East-Syria and Iraq for example-power-sharing and the management of ethnic and political divisions and tensions have had a long history in Lebanon-fraught with hazards and obstacles to be sure, but an important tradition of harmony and order nonetheless.

It is against this backdrop that Craig Larkin examines post-war history and "amnesia" in Lebanon, and the "emergence of new memory discourse" on the 1975 civil war. Larkin also deals with the idea of Lebanese nationalism and the way in which this nationalism has constructed national memory, as well as "war memory" in the country, and the role that this nationalism has played as instigator of "ethnic conflict, reconciliation, and peace-building."

It is particularly pleasing for a cultural historian to read Lebanon through Larkin's anthropologist's lens: his qualitative data and social observation often flow like narrative literature, offering gripping, fascinating, and supremely illuminating insights into Lebanon's ethnic tensions, contested histories, and clashing memories. It matters little whether the origins of the Lebanese go back to a Phoenician, Greek, Roman, or Arab progenitor, argues Larkin; what matters is that the Lebanese mountains have historically attracted the forefathers of the modern Lebanese; tormented minorities who, over time, formed the nucleus of autonomous "Ottoman Lebanon (1523-1915)," which would ultimately evolve into the modern Lebanese republic. Still, Larkin's work brings light to the variety of Lebanese identities-or in his telling "Lebanese nations" - that, despite their contradictory impulses, define "Lebanonness." Those competing visions of identity and "Lebanese particularism" include Maronite Phoenicianism, Sunni Arabism, Shi'ite Islamism, Greek-Orthodox pan-Syrianism, and bevies of multicultural, polyglot, and other incarnations of hybridity, pluralism, and even liminal transnationalism.

Larkin is admirably respectful of his subject matter. Never judgmental, never disdainful-even when dealing with ostensibly dubious claims-he approaches all of Lebanon's conflicting myths of origin with the same probity and the same fairmindedness. To wit, the belief in a Phoenician - rather than a presumptive Arabprogenitor of the modern Lebanese is prevalent among Maronites. Yet this is a myth of origin that is often ridiculed by mainstream scholarship on Lebanon; a discourtesy predicated largely on the claim that since the Lebanese are Arabophones, they then must be Arab. Of course the Anglophone parallel to this model, deeming, say, Scotsmen Irishmen or Liberians Englishmen, would be dismissed out of hand in a European or African context. Regardless, Larkin does not fall prey to such fashionable oversimplifications, according fair hearing to all of his subjects' nationalist predilections, giving dignity to both his academic discipline and 


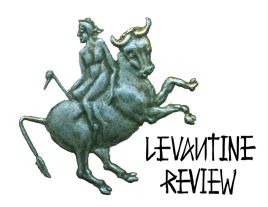

his subject-matter. Phoenicianism is one approach to defining Lebanese identity, writes Larkin,

but it should not be considered the only approach. Indeed the majority of students interviewed from across all religious and confessional divides favoured an allegiance to a collective Lebanese identity and a growing reluctance to be considered primarily Arab. This unease with an Arab identity flows more from cultural and social reasons than primordial bonds, and is founded more upon present experiences and perceptions than past images (p. 62.)

Indeed, Larkin goes on to make the argument that, rather than being a marginal idea of an inconsequential minority of Lebanese, Phoenicianism is rather a sophisticated doctrine, impugned by outsiders, but hardly by the Lebanese themselves.

Although written with minute attention to detail, Larkin's book could have benefitted from a number of minor edits. A few suggestions follow in the sampling below:

Michel Chiha was the father of the 1926 Lebanese Constitution, not the "1924 constitution" (p. 41.) Charles' Corm's canon of Lebanonism, La montagne inspirée, translates into the "Sacred" or "Hallowed Mountain," not the "Inspired Mountain" (p. 47.) In this regard, no adequate investigation of Charles Corm, Michel Chiha, and the brand of Lebanese patriotism that they inspired during the 1930s-1960s, can be properly engaged without consulting Asher Kaufman's Reviving Phoenicia. It is curious that Larkin's otherwise exhaustive bibliography (which includes Kaufman) would still forgo Kaufman's seminal work in the debate on/over Lebanese nationalism and its Cormian intellectual bearings. "Geographic Syria" in Arabic is "bilad al-Sham" not "balad al-Sham," and the "Arab conquest" is "al-fateh al-'Arabi," not "al-'arbi al-fitah" (p. 49.) Incidentally, up until 2001, Arab nationalists in Lebanon and elsewhere seemed unbothered by the rubric "Arab Conquest" in Lebanon's official history textbooks. The 2001 revisionist history of which Larkin speaks, instigated by the Ta'if Agreement, attempted to replace the "Arab Conquest" (al-fateh al-'Arabi) with the "Arab Expansion" (al-imtidaad al-'Arabi,) suggesting that Lebanon had always been Arab (or at least had always been home to Arabs,) with the seventh century conquest merely marking the beginning of a modern "expansion" of an already Arab or Arabized region. That is in fact the source of the controversy; the tempering of the Lebanonist "Phoenician narrative" - deemed falsified history by the Arabists-with another, this time an Arabist, historical howler. There are other, albeit non-substantive, elements of Larkin's work that should have been put under closer scrutiny: Lebanese political scientist and Director of the Carnegie Middle East Center in Beirut, for instance, is Paul Salem, not "Paul Salam" (p. 50.) Furthermore, the Shi'ite Southern region of Lebanon is "jabal 


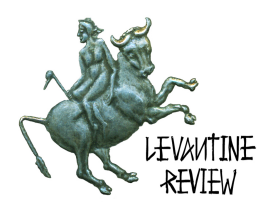

Amil" not "jabal Amal" (p. 51); and, finally, the "Ta'if Accord" was ratified by the Lebanese Parliament in November 1989, and is therefore commonly known as the "1989 Ta'if Accord," not the "1990 Ta'if Accord" (pp. 52-53 etc.)

It is often difficult to study or write about Lebanon without being ensnared in its charms. Lebanon, famously wrote A.R. Norton,

even in the worst of times, can be a remarkably seductive place [...]; no other Middle Eastern country, perhaps no country in the world, is as enthralling as Lebanon. Its social and political complexity, the keen skill of its citizens in dealing with (and manipulating) foreigners, and its lovely climate and splendid food combine to imbue those who have known it-in good times or bad-with a sense of emotional attachment that is hard to shake. Lebanon entices and ensnares even the wary. Though the encounter is often bittersweet, it is long savored. ${ }^{31}$

And so, although Larkin's fieldwork in Lebanon may have led him to surrender to the country's charms, his writing remains always sober, collected, impartial, and most of all decent, adding much needed substance depth and class to the literature on Lebanon's history and memory.

* Franck Salameh is Assistant Professor of Near Eastern Studies at Boston College, and author of Language Memory and Identity in the Middle East; The Case for Lebanon (Lexington, 2010 and 2011.) He is founding Senior Editor of The Levantine Review, and publishes frequently in leading academic journals, and in national and international media outlets on Lebanese history and the history of ideas in the Levant.

${ }^{31}$ A.R. Norton, Amal and the Shi'a; Struggle for the Soul of Lebanon (Austin: University of Texas Press, 1987), xiv. 